\title{
Missense Mutation in Exon 7 of the Common $\gamma$ Chain Gene Causes a Moderate Form of X-linked Combined Immunodeficiency
}

\author{
Frank C. Schmalstieg, ${ }^{\star}$ Warren J. Leonard," Masayuki Noguchi," Maria Berg," H. Elizabeth Rudloff, " Richard M. Denney, \\ Sanat K. Dave, ${ }^{\star}$ Edward G. Brooks, ${ }^{\star}$ and Armond S. Goldman ${ }^{\star *}$ \\ Departments of ${ }^{*}$ Pediatrics, ${ }^{\ddagger}$ Human Biological Chemistry and Genetics, and ${ }^{\S}$ Microbiology and Immunology, University of Texas \\ Medical Branch, Galveston, Texas 77555-0369; and the "Laboratory of Molecular Immunology, National Heart, Lung, and Blood \\ Institute, National Institutes of Health, Bethesda, Maryland 20892
}

\begin{abstract}
Clinical and immunologic features of a recently recognized $\mathrm{X}$-linked combined immunodeficiency disease (XCID) suggested that XCID and X-linked severe combined immunodeficiency (XSCID) might arise from different genetic defects. The recent discovery of mutations in the common $\boldsymbol{\gamma}$ chain $\left(\gamma_{c}\right)$ gene, a constituent of several cytokine receptors, in XSCID provided an opportunity to test directly whether a previously unrecognized mutation in this same gene was responsible for XCID. The status of $X$ chromosome inactivation in blood leukocytes from obligate carriers of XCID was determined from the polymorphic, short tandem repeats $(\mathrm{CAG})_{\mathrm{n}}$ in the androgen receptor gene, which also contains a methylation-sensitive HpaII site. As in XSCID, X-chromosome inactivation in obligate carriers of XCID was nonrandom in $T$ and $B$ lymphocytes. In addition, $X$ chromosome inactivation in PMNs was variable. Findings from this analysis prompted sequencing of the $\gamma_{c}$ gene in this pedigree. A missense mutation in the region coding for the cytoplasmic portion of the $\gamma_{c}$ gene was found in three affected males but not in a normal brother. Therefore, this point mutation in the $\gamma_{c}$ gene leads to a less severe degree of deficiency in cellular and humoral immunity than that seen in XSCID. (J. Clin. Invest. 1995. 95:1169-1173.) Key words: T lymphocyte $\bullet$ immunodeficiency $\bullet I L-2 R \cdot X$ chromosome $\bullet$ genetics
\end{abstract}

\section{Introduction}

In 1990, we reported a novel X-linked combined immunodeficiency (XCID) ${ }^{1}$ distinct from X-linked severe combined immunodeficiency (XSCID) in a large kindred of English origin (1). The patients displayed repeated, chronic bacterial infections of

Portions of this work appeared in abstract form (Pediatr. Res. 35:76A, 1994).

Address correspondence to Frank C. Schmalstieg, M.D., Ph.D., Division of Immunology/Allergy, Department of Pediatrics, The Children's Hospital, Room C-236, The University of Texas Medical Branch, Galveston, TX 77555-0369. FAX: 409-772-5045.

Received for publication 20 September 1994 and in revised form 10 November 1994.

1. Abbreviations used in this paper: $\mathrm{AR}$, androgen receptor; $\gamma_{\mathrm{c}}$, common $\gamma$ chain; SSCP, single-stranded conformational polymorphisms; XCID, $\mathrm{X}$-linked combined immunodeficiency; XSCID, X-linked severe combined immunodeficiency.

The Journal of Clinical Investigation, Inc. Volume 95, March 1995, 1169-1173 the middle ear, paranasal sinuses, bronchi, and lungs as well as severe or recurrent varicella, Herpes simplex, and papilloma virus infections. In contrast to XSCID, other opportunistic infections including Pneumocystis carrini pneumonia were not seen, and some affected males survived into late childhood or adulthood. This spectrum of infections suggested that both humoral and cellular immunity were deficient, but not to the degree found in XSCID. Indeed, serum immunoglobulin levels were normal, whereas they are decreased in XSCID. The formation of specific serum IgG and IgA antibodies was, however, profoundly diminished in XCID (1), most likely due to $\mathrm{T}$ cell defects. Indeed, CD4 and CD8 T cells were significantly decreased, but not to the extent seen in XSCID (1). XCID also differed from classical XSCID in that blood $\mathrm{T}$ cells were predominantly CD45RO+ and an increase in blood CD4+ T cells occurred postnatally $(1,2$, Finally, the variable region repertoire in $\mathrm{T}$ cell receptors $(\alpha / \beta)$ on blood $\mathrm{T}$ cells was altered in the affected males (3).

We investigated the molecular relationships between XCID and XSCID by three coupled approaches. First, we examined the pattern of $\mathrm{X}$ chromosome inactivation in blood T cells, Blymphoblastoid cells and PMNs from obligate carriers of the disease using the methylation status of the STR, $(C A G)_{n}$, in the AR gene, $(4,5)$ since nonrandom $X$ inactivation is found in carriers of XSCID (6-8). Second we examined whether the segregation of XCID was closely linked to the $\gamma_{c}$ gene, because mutations in that gene are responsible for XSCID (9). The segregation of XCID with polymorphisms of the androgen receptor (AR) gene (Xq11.1), intron 1 of the common $\gamma$ chain $\left(\gamma_{c}\right)$ gene $(X q 13)(9,10)$, and the dinucleotide repeat $(C A)_{n}$ in the DXS458 locus $(\mathrm{Xq} 23)(11,12)$ were investigated for this purpose. Finally, based upon findings from those studies, the $\gamma_{\mathrm{c}}$ gene from males affected with XCID was sequenced to determine if a mutation was present.

\section{Methods}

Subjects. The study was approved by the Institutional Review Board of the University of Texas Medical Branch. All subjects gave informed consent for the study. B-lymphoblastoid cell lines from all available carriers and affected males, and T cells and PMNs from six obligate carriers were investigated (Fig. 1). All the available carriers were in good health without evidence of infection at the time they were studied. Subjects used for linkage and heteroduplex study were chosen based on their lineage and availability. The three affected males whose genomic DNA was sequenced, were used because they each represented a separate branch of this family with affected males.

DNA isolation. Mononuclear cells and PMNs were prepared from heparinized venous blood by dextran sedimentation and Ficoll-Hypaque centrifugation (13). $T$ lymphocytes were purified using magnetic beads coupled to anti-CD3 (Miltenyi Biotec, Sunnyvale, CA) (14). The purity of the cell preparations was monitored by flow cytometry (1). B-lymph- 


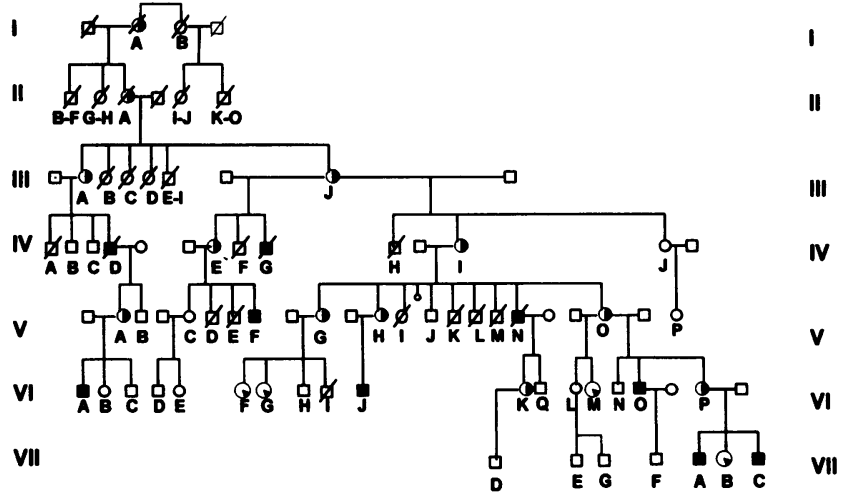

Figure 1. Pedigree of the kindred with XCID. The key for the symbols are as follows: Obligate carrier females (o); females with suspected carrier status based on non-random $\mathrm{X}$-inactivation $(\Theta)$; affected males $(\bowtie)$; miscarriage ( $b$ ). A diagonal line represents deceased family members. Individuals shown in subsequent figures are identified by generation number at the sides of the chart and a letter designation within generations.

oblastoid cell lines were produced by infection of blood B cells with Epstein-Barr virus (15). DNA from the cell preparations was obtained by NP-40 lysis, proteinase $\mathrm{K}$ digestion, and phenol-chloroform extraction (16) or by passage through DNA purification columns (Genomic DNA Isolation Kit, Boehringer Mannheim, Indianapolis, IN) according to the manufacturer's directions.

PCR amplification of the AR gene short tandem repeat (STR) and the dinucleotide repeat in the DXS458 locus. The sense (5'-TCCAGAATCTGTTCCAGAGCGTGC-3') and anti-sense ( $5^{\prime}$-GCTGTGAAGGTTGCTGTTCCTCAT-3') primers from the AR gene (12.5 pmol each) were mixed with $250 \mathrm{ng}$ of genomic DNA, $4 \mathrm{U}$ of Taq DNA polymerase, $250 \mu \mathrm{M}$ deoxynucleoside triphosphates (dNTPs) $(2.5 \mu \mathrm{Ci}$ $\left.\left[{ }^{32} \mathrm{P}\right] \mathrm{dCTP}[3,000 \mathrm{Ci} / \mu \mathrm{mole}]\right)$, and $1.5 \mathrm{mM} \mathrm{MgCl}_{2}(4)$ in the manufacturer's suggested buffer (Perkin-Elmer Cetus, Norwalk, CT) (total volume, $25 \mu \mathrm{l}$ ). DNA was amplified for 25 cycles at $95^{\circ} \mathrm{C}$ for $1 \mathrm{~min}, 65^{\circ} \mathrm{C}$ for $1 \mathrm{~min}$, and $72^{\circ} \mathrm{C}$ for $1 \mathrm{~min}$. Amplifications were preceded by a primary denaturation step $\left(95^{\circ} \mathrm{C}\right.$ for $\left.5 \mathrm{~min}\right)$ and followed by a final extension step $\left(72^{\circ} \mathrm{C}\right.$ for $\left.8 \mathrm{~min}\right)$ after the last cycle (4). When methylation status of the genomic DNA was examined by digestion with HpaII, the DNA (250 ng) was digested with HpaII (Promega) in a reaction volume of $4 \mu \mathrm{l}$ (in the manufacturer's recommended buffer) for $2 \mathrm{~h}$ at $37^{\circ} \mathrm{C}(17)$ before amplification. After addition of stop buffer, the samples were denatured at $95^{\circ} \mathrm{C}$ for $5 \mathrm{~min}$ and electrophoresed on $4 \%$ polyacrylamide/ $8 \mathrm{M}$ urea at $38 \mathrm{~W}$ for $2 \mathrm{~h}$. Resultant bands were visualized by ethidium bromide staining, or by radioautography using Hyperfilm-MP (Amersham Corp., Arlington Heights, IL). PCR conditions for amplification of the DSX458 locus were as follows: The sense (5'GATAAAACTGCATAGAAATGCG-3') and antisense ( $5^{\prime}$-CAACTGGGATATTGACATTG- $3^{\prime}$ ) primers ( 12.5 pmol each) were mixed with $20 \mathrm{ng}$ of genomic DNA, 1 unit of Taq DNA polymerase, $200 \mu \mathrm{M}$ dNTPs (2.5 $\mu \mathrm{Ci}\left[{ }^{32} \mathrm{P}\right] \mathrm{dCTP}[3,000 \mathrm{Ci} / \mu$ mole $\left.]\right)$, and $1.5 \mathrm{mM} \mathrm{MgCl}_{2}$ (18).

Analyses of polymorphisms of the $\gamma_{c}$ gene. SSCP analyses were performed as previously described (9). Sense ( $5^{\prime}$-GAATGAAGACACCACAGCTG- ${ }^{\prime}$ ) and anti-sense ( $5^{\prime}$-GGGCATAGTGGTCAGGAAG$\left.3^{\prime}\right)$ primers from intron 1 of the $\gamma_{\mathrm{c}}$ gene ( $1 \mu \mathrm{M}$ each) were mixed with $200 \mathrm{ng}$ of genomic DNA, $0.45 \mathrm{U}$ of Taq DNA polymerase, $200 \mu \mathrm{M}$ deoxynucleoside triphosphates (dNTPs), $25 \mu \mathrm{M}$ dCTP with $1 \mu \mathrm{Ci}$ of $\left[{ }^{32} \mathrm{P}\right] \mathrm{dCTP}$ and $1.0 \mathrm{mM} \mathrm{MgCl}{ }_{2}$ in the manufacturer's suggested buffer (Perkin-Elmer Cetus, Norwalk, CT) (total volume, $15 \mu \mathrm{l}$ ). The DNA was denatured $\left(94^{\circ} \mathrm{C}\right.$ for $\left.5 \mathrm{~min}\right)$, amplified for 30 cycles at $94^{\circ} \mathrm{C}$ for 1 min, $55^{\circ} \mathrm{C}$ for $1 \mathrm{~min}$, and $72^{\circ} \mathrm{C}$ for $1 \mathrm{~min}$ and followed by a final extension step $\left(72^{\circ} \mathrm{C}\right.$ for $\left.7 \mathrm{~min}\right)$ after the last cycle. After addition of stop buffer (USB), the samples were denatured at $95^{\circ} \mathrm{C}$ for $10 \mathrm{~min}$, quenched in an ice bath, and 4- $\mu$ l aliquots electrophoresed on nondenaturing $5 \%$ polyacrylamide gels at constant power $(25 \mathrm{~W})$ at room temperature or at $4^{\circ} \mathrm{C}$ for $2 \mathrm{~h}$. After drying, the resultant bands were visualized by autoradiography on Hyperfilm-MP (Amersham Corp.) exposed for $30 \mathrm{~min}$ to $1 \mathrm{~h}$ at $-70^{\circ} \mathrm{C}$

For heteroduplex formation, $4 \mu \mathrm{l}$ of PCR amplification products described in the SSCP analysis were mixed in pairs and heated to $95^{\circ} \mathrm{C}$ for $5 \mathrm{~min}$ and allowed to cool slowly to room temperature. The mixture was then added to $3 \mu \mathrm{l}$ of loading buffer ( $15 \%$ Ficol, $0.05 \%$ bromophenol blue, and $0.05 \%$ xylene cyanol) and $4 \mu \mathrm{l}$ of this mixture were then subjected to non-denaturing electrophoresis as described for the SSCP analysis.

Sequencing of the $\gamma_{c}$ gene. Genomic DNA from EBV-transformed B lymphocytes was utilized for nested-PCR amplifications of the $\gamma_{c}$ gene and subsequent dideoxy chain termination sequencing (9). For two patients, exon 7 was sequenced on the Applied Biosystems Model 373A automated sequencing system (Applied Biosystems, Foster City, CA) using the PRISM ${ }^{\mathrm{TM}}$ Ready Reaction DyeDeoxy ${ }^{\mathrm{TM}}$ Terminator Cycle Sequencing Kit (Applied Biosystems, Foster City, CA) according to the manufacturer's directions.

\section{Results}

$X$ chromosome inactivation in obligate carriers. Flow cytometry (FACScan ${ }^{\circledR}$, Becton-Dickinson, Moutainview CA) (1) was carried out on blood lymphocytes from three healthy carriers. The results (mean \pm standard deviation; normal values in parentheses) revealed normal profiles of blood $\mathrm{T}$ cells, $\mathrm{B}$ cells, and

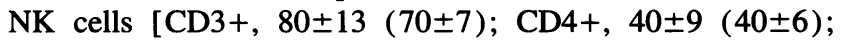
$\mathrm{CD} 8+, 28 \pm 12(21 \pm 6)$; CD19+, 13 \pm 3 (12 \pm 6$) ; \mathrm{CD} 16+, 4 \pm 1$ $(12 \pm 5)$.] In addition, over $95 \%$ of blood $T$ cells from two carriers that were tested were TCR $\alpha / \beta+$.

Products from the AR gene ranging from $\sim 280$ to 310 bp were produced by amplification of genomic DNA from T lymphocytes, B-lymphoblastoid cells, and PMNs of six obligate carriers. When the genomic DNA was digested with HpaII, one band predominated in the amplified DNA from T cells (Fig. 2 $A$ ) and B-lymphoblastoid cells (Fig. $2 B$ ), but both bands were variably amplified in the case of PMNs (Fig. $2 C$ ). Those findings indicated that $\mathrm{X}$ chromosome inactivation in XCID carriers was non-random in T and B cells, but variable in PMNs from obligate carriers. An exception to this pattern was detected in one carrier female (Fig. 3). This woman exhibited nonrandom $\mathrm{X}$ chromosome inactivation in $\mathrm{T}$ cells, B-lymphoblastoid cells, and PMNs. X chromosome use for her T cells was similar to that found in the other obligate carriers. However, the maternally derived, abnormal $\mathrm{X}$ chromosome was used in her B-lymphoblastoid cells and PMNs (Fig. 3).

Polymorphism analyses of the $\gamma_{c}$ gene. SSCP analysis for intron 1 and intron 2 of the $\gamma_{c}$ was uninformative. ${ }^{2}$ However, heteroduplex formation between distinct alleles in intron 1 was found (Fig. $4 A$, VI-O, an affected male and VI-N, his normal brother) by mixing experiments. In addition, several obligate carriers also demonstrated heteroduplexes, indicating heterozygosity (Fig. $4 \mathrm{~B}$ ). Subsequently, the entire $\gamma_{\mathrm{c}}$ gene was sequenced for individuals VI-N and VI-O. VI-O, but not VI-N,

\footnotetext{
2. A polymorphism in intron 1 of the $\gamma_{\mathrm{c}}$ gene detected by SSCP analysis was previously reported in abstract form (Pediatr. Res. 35:76A, 1994). This apparent polymorphism was secondary to heteroduplex formation under the conditions the assay was performed. If the assay is performed under conditions precluding heteroduplex formation, no polymorphism by SSCP analysis is observed.
} 


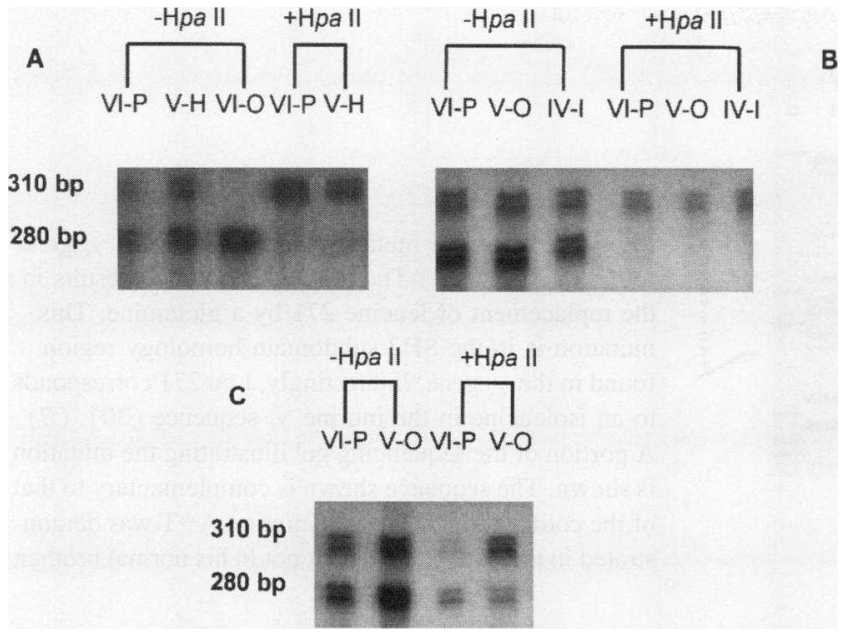

Figure 2. X chromosome inactivation in blood T lymphocytes, B-lymphoblastoid cells, and PMNs using the methylation status of the (CAG) STR loci of the AR gene. Genomic DNA was digested or not digested with Hpall before amplification. The 310- and 280-bp polymorphisms were then demonstrated by autoradiography after electrophoresis in $4 \%$ polyacrylamide/ $8 \mathrm{M}$ urea gels. Five different alleles for the AR gene were represented in this family. $(A)$ T lymphocytes: The 310 - and 280 bp polymorphisms were demonstrated in two females ( $\mathrm{V}-\mathrm{H}$ and VI-P) before HpalI digestion. In both cases, the lower band was absent after HpaII digestion, indicating nonrandom $\mathrm{X}$-inactivation and that the 310bp band was derived from the maternal $\mathrm{X}$ chromosome. An affected male, VI-O, son of V-O exhibited the 280-bp band and indicated a crossover event involving the AR locus. $(B)$ B lymphocytes: the 280and 310-bp polymorphisms were found in EBV-transformed lymphocytes from carriers VI-P and V-O, but a slightly higher molecular weight lower band is seen in carrier IV-I. Only the 310-bp band is visible when DNA from these carriers was digested with HpaII before amplification indicating non-random $\mathrm{X}$ chromosome inactivation in these lymphoblastoid cells. $(C)$ PMNs: The 310- and 280-bp bands were present in differing amounts after Hpall digestion of DNA from carriers VI-P and $\mathrm{V}-\mathrm{O}$. This is representative of other carriers (data not shown) and indicates variable $\mathrm{X}$ chromosome inactivation in PMNs.

demonstrated a missense mutation at amino acid 271 (leucine $\rightarrow$ glutamine) corresponding to a (CTG $\rightarrow$ CAG) change in exon 7 (Fig. 5). Subsequent sequencing of two additional affected males (V-F and VI-A) confirmed the same mutation in the $\mathrm{SH} 2$ subdomain region (Fig. 5).

Genetic analysis of XCID. Polymorphisms in the AR gene,

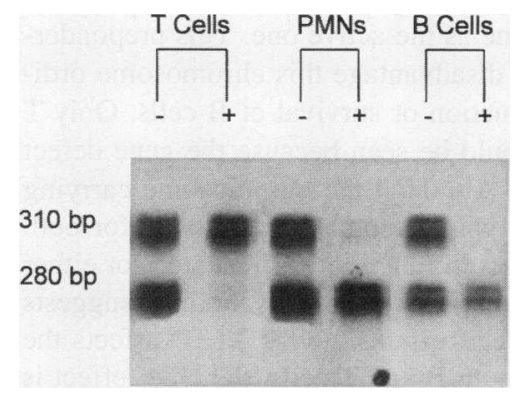

Figure 3. Alternative $\mathrm{X}$ chromosome usage for blood $\mathrm{T}$ lymphocytes and EBV-transformed B lymphocytes and PMNs in one female carrier. $X$ chromosome inactivation was non-random in $\mathrm{T}$ cells, B-lymphoblastoid cells, and PMNs. T cells used the paternally derived $\mathrm{X}$ chromosome and B-lymphoblas-

toid cells and PMNs used the maternally derived $\mathrm{X}$ chromosome. The + and - designations are for digestion or no digestion, respectively, with HpaII before PCR amplification of the STR in the AR gene.

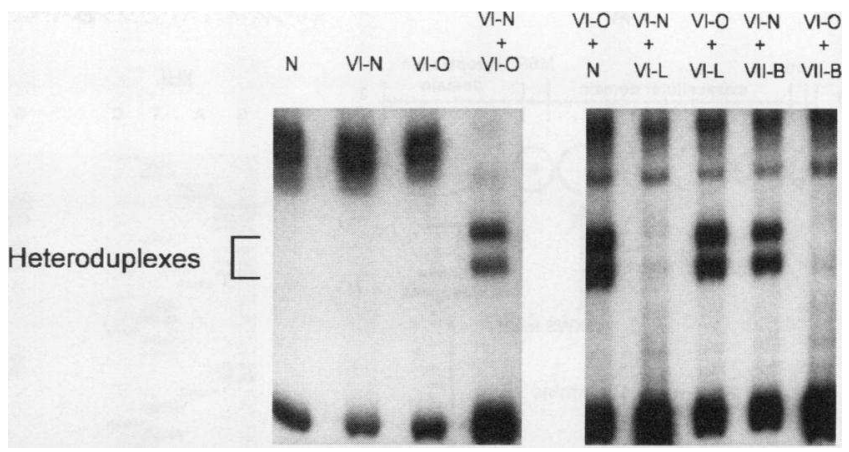

Figure 4. Heteroduplex analysis of intron 1 of the $\gamma_{\mathrm{c}}$ gene. (Left) Heteroduplex formation between affected (VI-O) and non-affected (VI-N) males. $\mathrm{N}$ is a normal unaffected male not found in the pedigree. In this analysis, each allele was amplified separately and then mixed (VI-O + VI-N). (Right) Confirmation of carrier status by heteroduplex formation. In this analysis, DNA from either VI-N or VI-O was mixed with females VII-B or VI-L before amplification. The amplified products were subjected to heteroduplex formation as described in Methods, and VII-B, but not VI-L, was confirmed to be a carrier. Note that mixing experiments are not necessary in those females who are heterozygous at this locus since heteroduplexes form from the two different alleles already present.

$\gamma_{\mathrm{c}}$ gene, and the DXS458 locus were examined in available members of the XCID pedi gree (Fig. 6). Recombination events were seen between the disease locus and the AR gene, but not the DXS458 locus, or the $\gamma_{\mathrm{c}}$ gene. Two other affected males (data not shown) also shared the same $\gamma_{\mathrm{c}}$ gene allele as the three males shown. Heteroduplex analysis was used to determine the occurrence of the disease-associated allele in each affected male and certain suspected carriers. Chromosomal assignments of the alleles in females were made on the basis of least numbers of recombination events and contributions of the paternal chromosomes. This analysis allowed prediction of the carrier status of these individuals (Fig. 6).

\section{Discussion}

The discovery of the defect in the $\gamma_{\mathrm{c}}$ gene in XSCID (9) provided an opportunity to test whether a defect in the same gene was responsible for XCID. Single stranded conformational polymorphisms were sought in intron 1 and intron 2 of the $\gamma_{c}$ gene in the XCID kindred. This analysis was uninformative. ${ }^{2}$ Further evidence for allelic difference in intron 1 was examined by heteroduplex analysis. Mixing experiments between the DNA from an affected and unaffected brother demonstrated heteroduplex formation. This strongly suggested that allelic differences were present in the $\gamma_{c}$ gene from these two individuals. Further genetic analysis employing mixing experiments between these two males and other individuals from the XCID pedigree was consistent with linkage of the disease to the $\gamma_{c}$ gene. Two flanking loci, the AR gene and the DXS458 loci $(4,5)$, were also examined in this family. Although limited recombination events were detected, the data suggested linkage to these loci as well. These findings led to the sequencing of the $\gamma_{c}$ gene in one of the affected males and his unaffected brother. A missense mutation in exon $7(10,19)$ (leucine $271 \rightarrow$ glutamine) was found in patient VI-O, but not in his normal brother (VI-N). The same missense mutation was subsequently found in two other affected males (V-F and VI-A). 


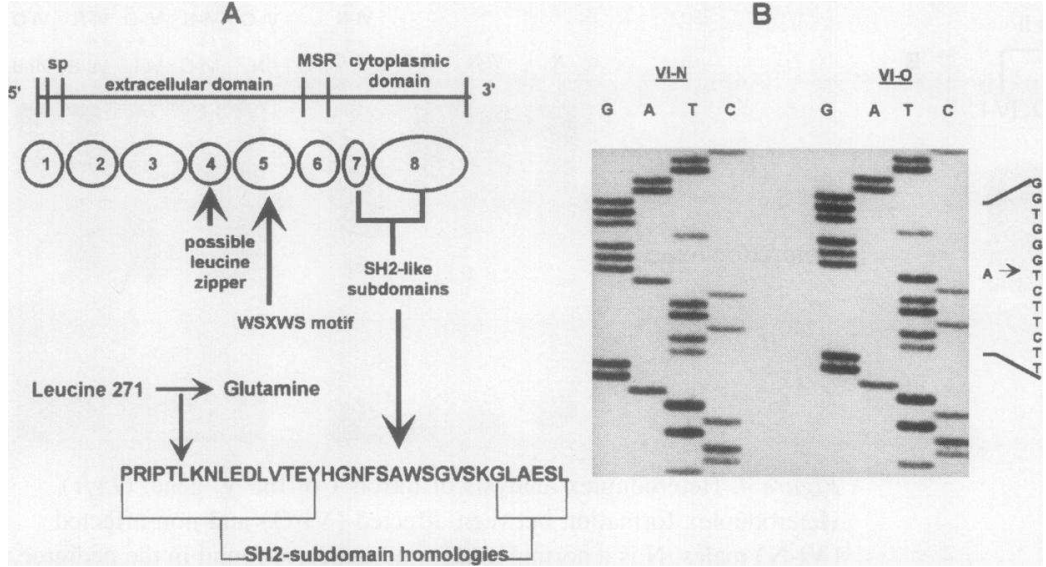

Figure 5. Missense mutation in exon 7 of the $\gamma_{\mathrm{c}}$ gene found in XCID. (A) The missense mutation results in the replacement of leucine 271 by a glutamine. This mutation is in the $\mathrm{SH} 2$ subdomain homology region found in the $\gamma_{\mathrm{c}}$ gene. Interestingly, Leu 271 corresponds to an isoleucine in the murine $\gamma_{\mathrm{c}}$ sequence (30). (B) A portion of the sequencing gel illustrating the mutation is shown. The sequence shown is complementary to that of the coding strand. The substitution $\mathrm{A} \rightarrow \mathrm{T}$ was demonstrated in the patient VI-O, but not in his normal brother.

The site of the mutation in the $\gamma_{c}$ gene in this more moderate combined immunodeficiency is distinct from previously published defects in this gene associated with XSCID. In XSCID, premature stop codons, presumably resulting in truncated proteins, were reported (9). In contrast, the missense mutation associated with XCID is in the first of two SH2 subdomain homology regions of the cytoplasmic portion of the molecule $(10,19)$. Although high affinity IL-2R would be expected to form, the amino acid substitution in a phosphopeptide binding domain suggests that this error causes a defective association of this receptor with proteins important in intracellular signaling. Recent evidence in favor of this speculation was obtained re-

N

$\mathbf{v}$

n

VI

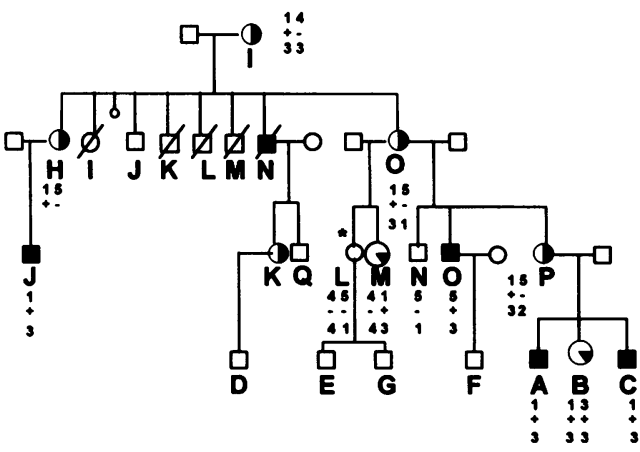

N

$\mathbf{v}$

n

VI

Figure 6. Genetic Analysis of XCID. Polymorphisms in the AR gene, $\gamma_{\mathrm{c}}$ gene, and the DXS458 locus were examined in the XCID pedigree. Alleles were assigned as arbitrary numbers for the AR gene (top number and the DXS458 locus (bottom number), respectively. Alleles were assigned to the maternal or paternal $\mathrm{X}$ chromosomes according to the most probably inheritance patterns. The status of the $\gamma_{\mathrm{c}}$ gene was designated as + or - based on heteroduplex analysis. It is possible that more than two alleles are involved in this pedigree. In this analysis, $(+)$ means only that the amplified segment from intron 1 does not form a heteroduplex with DNA from an affected male (VI-O) and therefore is the same allele, whereas $(-)$ indicates that a heteroduplex is formed. In the case of heterozygous females that were obligate carriers, no mixing experiments were conducted since heteroduplexes formed from the two different autologous alleles. A recombination event involving the region of the $\mathrm{X}$ chromosome containing the AR gene, but not the DXS458 locus or the $\gamma_{\mathrm{c}}$ gene was observed in one affected male (VI$\mathrm{O})$. The asterisk at VI-L denotes nonrandom $\mathrm{X}$-inactivation without carrier status. This finding most likely represents skewed $\mathrm{X}$-inactivation that is found occasionally in normal females. garding the association of JAK-3, a member of the Janus family of protein tyrosine kinases, with $\gamma_{c}(20)$.

The status of $\mathrm{X}$ chromosome inactivation is also of interest in this disease. Investigations of $\mathrm{X}$ chromosome inactivation in female carriers of $\mathrm{X}$-linked immunodeficiency diseases have been useful both in detecting carriers $(6,7,8)$ and in understanding the basis of some of those defects (21-23). It is assumed that nonrandom $\mathrm{X}$ chromosome inactivation arises from a survival or production disadvantage of cells in which the defective $X$ chromosome is the active one $(6,21)$. In that regard, there is preferential use of the paternal $\mathrm{X}$ chromosome in T cells and B cells in most female carriers of XSCID $(7,24)$. Furthermore, a preferential use of the paternal $\mathrm{X}$ chromosome in blood leukocytes from carrier females of an XSCID variant has also been reported (25).

In this study, we used the STR, (CAG) $)_{n}$, in the androgen receptor gene, which is differentially methylated in active and inactive $X$ chromosomes $(4,5)$. Obligate female carriers of this novel XCID were heterozygous and had patterns consistent with nonrandom $X$ chromosome inactivation in T cells, B cells, and variable $\mathrm{X}$ chromosome inactivation in PMNs with the exception of one carrier female. This individual, surprisingly, utilized the paternal $\mathrm{X}$ chromosome for $\mathrm{T}$ cells and the maternal $\mathrm{X}$ chromosome for B cells and PMNs. One possibility for this finding is that she had a spontaneous mutation in the "unaffected" X chromosome that produced a second defect that was disadvantageous for the survival or production of $B$ cells and PMNs. It seems more likely that skewed lyonization towards the maternal $X$ chromosome occurred in this carrier (26). In this scenario, a preponderance of precursor cells would utilize the maternal $\mathrm{X}$ chromosome as the active one. This preponderance would overcome the disadvantage this chromosome ordinarily confers on the production or survival of B cells. Only T cells of paternal origin would be seen because the gene defect is more lethal for T cells. Although the chromosome carrying the gene defect for XCID was presumably employed for both $B$ cells and PMNs, no defect in function was detected for either cell type (data not shown). Therefore, this finding suggests that although the gene defect responsible for XCID affects the production or survival of both B and T cells, the chief effect is directed at $\mathrm{T}$ cell function. This does not preclude more subtle defects in B cell function.

In summary, patients with XCID demonstrate a point mutation in the gene that codes for the intracellular portion of the 
$\gamma_{\mathrm{c}}$ protein. This newly recognized mutation promises to provide new insights into the function of the IL-2R $\gamma$ chain. The explanation for the disparate clinical findings in XCID and XSCID remains an important question. There is a precedent in that very different symptomatology also results from specific mutations in the $B$ cell tyrosine kinase gene in human $X$-linked agammaglobulinemia and CBA/N mice $(27,28)$. However, because $\gamma_{c}$ is not only a part of the $\operatorname{IL}-2 \mathrm{R}(9,10,19,29)$, but also a constituent of the IL-4 (30), IL-7 $(31,32)$, IL-9 (20), and IL15 (33) receptors, the task of unraveling the molecular pathogenesis of the resultant immunodeficiencies in this XCID will be complex. However, since mature $\mathrm{T}$ and $\mathrm{B}$ cells may be obtained from the affected males, and transgenic animals with the disease mutation may be constructed, it may be possible in the near future to understand further the consequences of this defect upon the development and function of the immune system.

\section{Acknowledgments}

We thank Mary Douglas for her kind assistance in preparing the B-lymphoblastoid cell lines, and Dr. O. Wesley McBride for critical comments. We also thank Dr. A. P. Lookingbill, Dr. H. M. Rosenblatt, and Dr. R. Kelly for their clinical assistance with these patients.

This work was supported in part by the John Sealy Memorial Endowment to the University of Texas Medical Branch in Galveston, Texas.

\section{References}

1. Brooks, E. G., F. C. Schmalstieg, D. P. Wirt, H. M. Rosenblatt, L. T. Adkins, D. P. Lookingbill, H. E. Rudloff, T. A. Rakusan, and A. S. Goldman 1990. A novel X-linked combined immunodeficiency disease. J. Clin. Invest. 86:1623-1631

2. Schmalstieg, F. C., D. P. Wirt, L. T. Adkins, E. G. Brooks, S. D. Stansberry, L. E. Swischuk, and A. S. Goldman. 1992. Postnatal development of T lymphocytes in a novel X-linked immunodeficiency disease. Clin. Immunol. Immunopathol. 64:71-77.

3. Goldman, A. S., K. H. Palkowetz, H. E. Rudloff, E. G. Brooks, and F. C. Schmalstieg. 1992. Repertoire of $\mathrm{V} \alpha$ and $\mathrm{V} \beta$ regions of $\mathrm{T}$ cell antigen receptors on CD4+ and CD8+ peripheral blood $\mathrm{T}$ cells in a novel $\mathrm{X}$-linked combined immunodeficiency disease. Eur. J. Immunol. 22:1103-1106.

4. La-Spada, A. R., E. M. Wilson, D. B. Lubahn, A. E. Harding, and K. H. Fischbeck. 1991. Androgen receptor gene mutations in X-linked spinal and bulbar muscular atrophy. Nature (Lond.). 352:77-79.

5. Allen, R. C., H. Y. Zoghbi, A. B. Moseley, H. M. Rosenblatt, and J. W. Belmont. 1992. Methylation of HpaII and HhaI sites near the polymorphic CAG repeat in the human androgen-receptor gene correlates with $\mathrm{X}$ chromosome inactivation. Am. J. Hum. Genet. 51:1229-1239.

6. Conley, M. E., A. Lavoie, C. Briggs, P. Brown, C. Guerra, and J. M. Puck 1988. Nonrandom $X$ chromosome inactivation in B cells from carriers of $X$ chromosome-linked severe combined immunodeficiency. Proc. Natl. Acad. Sci. USA. 85:3090-3094.

7. Puck, J. M., R. L. Nussbaum, and M. E. Conley. 1987. Carrier detection in $\mathrm{X}$-linked severe combined immunodeficiency based on patterns of $\mathrm{X}$ chromosome inactivation. J. Clin. Invest. 79:1395-1400.

8. Puck, J. M., C. C. Stewart, and R. L. Nussbaum. 1992. Maximum-likelihood analysis of human $\mathrm{T}$-cell $\mathrm{X}$ chromosome inactivation patterns: normal women versus carriers of $\mathrm{X}$-linked severe combined immunodeficiency. Am. J. Hum. Genet. 50:742-748.

9. Noguchi, M., H. Yi, H. M. Rosenblatt, A. H. Filipovich, S. Adelstein, W. S Modi, W. McBride O, and W. J. Leonard. 1993. Interleukin-2 receptor $\gamma$ chain mutation results in $\mathrm{X}$-linked severe combined immunodeficiency in humans. Cell. 73:147-157.

10. Noguchi, M., S. Adelstein, X. Cao, and W. J. Leonard. 1993. Characterization of the human interleukin-2 receptor $\gamma$ chain gene. J. Biol. Chem. 268:1360113608.

11. Weber, J. L., A. E. Kwitek, P. E. May, M. H. Polymeropoulos, and S.
Ledbetter. 1990. Dinucleotide repeat polymorphisms at the DXS453, DXS454, and DXS458 loci. Nucleic Acids Res. 18:4037.

12. Edwards, A., H. A. Hammond, L. Hin, C. T. Caskey, and R. Chakraborty. 1992. Genetic variation at five trimeric and tetrameric tandem repeat loci in four human population groups. Genomics. 12:241-253.

13. Boyum, A. 1968. Isolation of mononuclear cells and granulocytes from human blood. Scand. J. Clin. Lab. Invest. 21 (suppl. 97):77-89.

14. Manyonda, I. T., A. J. Soltys, and F. C. Hay. 1992. A critical evaluation of the magnetic cell sorter and its use in the positive and negative selection of CD45RO+ cells. J. Immunol. Methods. 149:1-10.

15. Straub, C., and R. H. Zubler. 1989. Immortalization of EBV-infected B cells is not influenced by exogenous signals acting on B cell proliferation. Effects of mutant EL-4 thymoma cells and transforming growth factor-beta. J. Immunol. 142:87-93.

16. Sambrook, J., E. F. Fritsch, and T. Maniatis. 1989. Molecular Cloning: A Laboratory Manual. Cold Spring Harbor Laboratory Press, Cold Spring Harbor, NY.

17. Vogelstein, B., E. R. Fearon, S. R. Hamilton, A. C. Preisinger, H. F. Willard, A. M. Michelson, A. D. Riggs, and S. H. Orkin. 1987. Clonal analysis using recombinant DNA probes from the X-chromosome. Cancer Res. 47:48064813.

18. Huang, T. H., R. W. Cottingham, Jr., D. H. Ledbetter, and H. Y. Zoghbi. 1992. Genetic mapping of four dinucleotide repeat loci, DXS453, DXS458, DXS454, and DXS424, on the X chromosome using multiplex polymerase chain reaction. Genomics. 13:375-380.

19. Takeshita, T., H. Asao, K. Ohtani, N. Ishii, S. Kumaki, N. Tanaka, H. Munakata, M. Nakamura, and K. Sugamura. 1992. Cloning of the $\gamma$ chain of the human IL-2 receptor. Science (Wash. DC). 257:379-382.

20. Russell, S. M., J. A. Johnston, M. Noguchi, M. Kawamura, C. M. Bacon, M. Friedman, M. Berg, D. W. McVicar, B. A. Witthuhn, O. Silvennoinen, and A. S. Goldman, F. C. Schmalstieg, J. N. Ihle, J. J. O'Shea, and W. J. Leonard. 1994. Interaction of IL-2 receptor $\beta$ and $\gamma_{\mathrm{c}}$ chains with JAK1 and JAK3, respectively: defective $\gamma_{\mathrm{c}}$-JAK3 association in XSCID. Science (Wash. DC). 266:10421044.

21. Cooper, M. D., and A. R. Lawton. 1972. Circulating B-cells in patients with immunodeficiency. Am. J. Pathol. 69:513-528.

22. Vetrie, D., I. Vorechovsky, P. Sideras, J. Holland, A. Davies, F. Flinter, L. Hammarstrom, C. Kinnon, R. Levinsky, M. Bobrow, C. I. E. Smith, and D. R. Bentley. 1993. The gene involved in X-linked agammaglobulinaemia is a member of the src family of protein-tyrosine. Nature (Lond.). 361:226-233.

23. Tsukada, S., D. C. Saffran, D. J. Rawlings, O. Parolini, R. C. Allen, I. Klisak, R. S. Sparkes, H. Kubagawa, T. Mohandas, S. Quan, J. W. Belmont, M. D. Cooper, M. E. Conley, and O. N. Witte. 1993. Deficient expression of a B cell cytoplasmic tyrosine kinase in human X-linked agammaglobulinemia. Cell. 72:279-290

24. Conley, M. E., and J. M. Puck. 1988. Definition of the gene loci in Xlinked immunodeficiencies. Immunol. Invest. 17:425-463.

25. de Saint-Basile, G., F. Le-Deist, M. Caniglia, Y. Lebranchu, C. Griscelli, and A. Fischer. 1992. Genetic study of a new X-linked recessive immunodeficiency syndrome. J. Clin. Invest. 89:861-866.

26. Gale, R. E., H. Wheadon, and D. C. Linch. 1991. X-chromosome inactivation patterns using HPRT and PGK polymorphisms in haematologically normal and post-chemotherapy females. Br. J. Haematol. 79:193-197.

27. Thomas, J. P., P. Sideras, C. I. E. Smith, I. Vorechovsky, V. Chapman, and W. E. Paul. 1993. X-linked agammaglobulinemia and X-linked immunodeficiency genes. Science (Wash. DC). 261:355-358

28. Rawlings, J. D., D. C. Saffran, S. Tsukada, D. A. Largaespada, F. C. Grimaldi, L. Cohen, R. N. Mohr, J. F. Bazan, M. Howard, N. G. Copeland, N. A. Jenkins, and O. N. Wittig. 1993. Mutation of unique region of Bruton's tyrosine kinase in immunodeficient XID mice. Science (Wash. DC). 261:358-361.

29. Cao, X., C. A. Kozak, Y. J. Liu, M. Noguchi, E. O'Connell, W. J. Leonard. 1993. Characterization of cDNAs encoding the murine interleukin 2 receptor (IL2R) $\gamma$ chain: chromosomal mapping and tissue specificity of IL-2R $\gamma$ chain expression. Proc. Natl. Acad. Sci. USA. 90:8464-8468.

30. Kondo, M., T. Takeshita, N. Ishii, M. Nakamura, S. Watanabe, K. Arai, and K. Sugamura. 1993. Sharing of the interleukin-2 (IL-2) receptor $\gamma$ chain between receptors for IL-2 and IL-4. Science (Wash. DC). 262:1874-1877.

31. Noguchi, M., Y. Nakamura, S. M. Russell, S. F. Ziegler, M. Tsang, X. Cao, and W. J. Leonard. 1993. Interleukin-2 receptor $\gamma$ chain: a functional component of the interleukin-7. Science (Wash. DC). 262:1877-1880.

32. Kondo, M., T. Takeshita, M. Higuchi, M. Nakamura, T. Sudo, S. Nishikawa, and K. Sugamura. 1994. Functional participation of the IL-2 receptor $\gamma$ chain in IL-7 receptor complexes. Science (Wash. DC). 263:1453-1454.

33. Giri, J. G., M. Ahdleh, J. Eisenman, K. Shanebeck, S. Grabstein, A. Kumake, L. Nmaen, S. Park, D. Cosman, and D. Anderson. 1994. Utilization of the $\beta$ and $\gamma$ chains of the IL-2 receptor by the novel cytokine IL-15. EMBO (Eur. Mol. Biol. Organ.) J. 13:2822-2830. 